\title{
Maximizing the efficacy of Trichoderma to control Cephalosporium maydis, causing maize late wilt disease, using freshwater microalgae extracts
}

\author{
Ibrahim E. Elshahawy ${ }^{1 *}$ and Abo El-Khair B. El-Sayed ${ }^{2}$
}

\begin{abstract}
The main goal of this study was enhancing the biocontrol activity of Trichoderma spp. (T. harzianum, T. koningii, T. viride, and T. virens) against Cephalosporium maydis, the cause of late wilt disease in maize. Five isolates of C. maydis were isolated from diseased maize plants, showing late wilt symptoms, and were collected from infected maize fields in Gharbia Governorate, Egypt. Pathogenicity test revealed that all C. maydis isolates were able to attack maize plants (cv. Baladi), which cause late wilt disease. Isolate $3(\mathrm{Cm} 3)$ was the most virulent of them. In in vitro experiments, vegetative growth of the mycelium of C. maydis was highly inhibited after opposite sides' treatment by Trichoderma species on Potato Dextrose Agar plates amended with Chlorella vulgaris extracts (cool and hot extracts) than unamended one. Formulation of C. vulgaris extracts and Trichoderma spp. were prepared. The formulations maintained the capacity of Trichoderma spp. to inhibit growth of the pathogen for up to 1 year when stored at both room temperature or at $7^{\circ} \mathrm{C}$. These formulations (3-day-old) were examined for biological control activities against late wilt disease of maize. Under greenhouse and field conditions, all treatments reduced late wilt incidence compared to the untreated control. Treatments involved Trichoderma spp., and C. vulgaris extracts were more effective than that used individually. Both of the C. vulgaris extracts, with each of T. virens and T. koningii, were the most effective treatments in this respect. Under greenhouse conditions, formulation treatments $(C$. vulgaris extracts and Trichoderma spp.) significantly increase the plant growth of maize plants, i.e., plant height and plant dry weight as compared to the non-treated control either in infested or in un-infested soil with C. maydis. Under field conditions, these formulations increased the grain yield as well as ear parameters as compared with either $C$. vulgaris extracts or Trichoderma spp. alone as well as non-treated control. This study suggests that the efficacy of Trichoderma spp. was enhanced with C. vulgaris extracts and these formulations can be developed as bio-fungicides for minimizing the late wilt disease caused by C. maydis in maize.
\end{abstract}

Keywords: Chlorella vulgaris extract, Late wilt disease, Maize plants, Trichoderma spp., Biological control

\section{Background}

Maize, Zea mays L., is one of the most important cereal crops worldwide. In Egypt, the cultivated maize area reached about 88,000 ha that yielded almost 7.2 million metric tons of grains (Anonymous 2017). Black bundle disease or late wilt, caused by Cephalosporium maydis, is one of the main economical and distributed maize diseases in Egypt (Samra et al. 1963). This disease appears

\footnotetext{
* Correspondence: ibrahim_nrc@yahoo.com

${ }^{1}$ Plant Pathology Department, National Research Centre, Giza, Egypt Full list of author information is available at the end of the article
}

during tasseling as a rapid wilting of the lower leaves and develops to hollow and shrunken stalks with a dark yellow-to-brown or black-stained pith (El-Shafey and Claflin 1999). The pathogen is a soil-borne vascular wilt disease that enters tissue of the root and colonizes the xylem (Sabet et al. 1970). Less commonly, this pathogen can be seed-borne (E1-Shafey et al. 1976) and may irregularly cause decay of seed or pre-emergence damping-off under heavy inoculum pressure (Sabet et al. 1970). This fungus duplicates asexually and has not been in perfect stage (Saleh and Leslie 2004). Large economic 
losses have been reported in Egypt by late wilt disease. In susceptible varieties, the disease affected $70 \%$ of the plants decreasing the grain yield by $40 \%$ (Labib et al. 1975). Breeding of resistant varieties of maize is the most effective method for controlling this disease (El-Shafey et al. 1988). Various bacteria and actinomycetes have been evaluated as biocontrol agents against late wilt disease (El-Mehalowy et al. 2004 and Ashour et al. 2013). Little information has been cited in the literature on the efficiency of Trichoderma spp. against late wilt disease. Trichoderma spp. isolated from Egyptian soil were used as a biocontrol for Colletotrichum dracaenophilum and Fusarium proliferatum, based on results of laboratory trials (Morsy and Elshahawy 2016 and Elshahawy et al. 2017a). It reduced disease caused by the soil-borne fungus Stromatinia cepivora (Berk.) and induced plant resistance in onion plants when applied to soil (Elshahawy et al. 2017b).

The microalgae, Chlorella vulgaris known as freshwater algae, is one of the most remarkable green microalgae. There are several applications and potential benefits of this microalga such as biofuels, human nutrition, animal feed, wastewater treatment, and agrochemical applications (Safi et al. 2014). C. vulgaris contains high amounts of micro- and macronutrients, proteins, and carbohydrates (Wake et al. 1992). It is used as bio-fertilizer and soil conditioner in agriculture systems (Song et al. 2005). Algal extract can be partially substituting micronutrient foliar fertilizers and best to be complementary portion of the spray solution (Shabaan 2010). Soil fertility can be improved by entrapping some rhizosphere bacteria with Chlorella (Raposo and Morais 2011). Newly, the consortium of C. vulgaris, Azotobacter sp., and Anabaena variabilis was found to increase germination and plant growth of rice, and it is suggested as a bio-fertilizer and a bio-stimulator for crops as reported by Zayadan et al. (2014).

The present study was conducted to evaluate the efficiency of Trichoderma species either alone or mixed with the $C$. vulgaris extracts on the incidence of maize with late wilt under greenhouse and field conditions.

\section{Materials and methods}

\section{Experimental site}

This study was carried out at the Agriculture and Biological Division, National Research Centre (NRC), as well as within a disease nursery field located at Gharbia Governorate, Egypt, during the 2016 growing season.

Freshwater microalgae, Chlorella vulgaris, and preparation of extracts

C. vulgaris was isolated from freshwater Nile River at Cairo Governorate, Egypt (El-Sayed et al. 2001). This strain was massively produced at Algal Biotechnology
Unit, National Research Centre, Giza, Egypt. The cultivation was performed, using a 1200-l open-plate photobioreactor. Microalgae nutrition was performed as described by El-Sayed et al. (2015). Grown culture was concentrated and dewatered by gravity. Purification of the obtained biomass was performed by a series of precipitation by cooling centrifuge and washing it using tap water. This procedure was repeated several times to remove any excess of nutrients and mineral elements. The obtained biomass was dried at $45{ }^{\circ} \mathrm{C}$ within a circulated oven and then ground to a fine powder (Hassan et al. 2015).

Hot $\left(\right.$ at $\left.70{ }^{\circ} \mathrm{C}\right)$ and cool water extracts were produced by soaking $10 \%$ of microalgae biomass with distilled water and solicited using ultrasonic homogenizer. After homogenization, the extracted materials were obtained by filtration through filter paper (Whatman no. 1). The extracts were freeze-dried and sieved in a refrigerator until used. Total sugars were determined according to Dubois et al. (1956). Polysaccharides were determined in extracts. Firstly, freeze-dried extracts were sequentially treated by petroleum ether and chloroform to remove oiled materials. Absolute ethanol was used to precipitate polysaccharides. Forty milliliters of absolute ethanol was added gradually to $10 \mathrm{ml}$ of water extracts $(1: 20 \mathrm{w} / \mathrm{v})$. The mixtures were left overnight into the refrigerator and then centrifuged (5500 rpm for $10 \mathrm{~min}$ ). The precipitated polysaccharides were dried using a freeze drier and determined by gas-liquid chromatography (GLC).

\section{Trichoderma species}

Four Trichoderma species, viz., T. harzianum, T. koningii, T. viride, and T. virens, were obtained from Plant Pathology Department, NRC, Egypt. The Trichoderma species were isolated from Egyptian soil, identified, and evaluated for their efficiency in previous study (Elshahawy et al. 2016).

\section{C. maydis isolates}

Maize plant samples, showing typical late wilt symptoms, were collected from naturally infected fields located at Gharbia Governorate, Egypt. Isolation of $C$. maydis was carried out according to Samra et al. (1963). Stems of diseased maize plants were cut into small pieces, and the surface was disinfected with $0.5 \%$ sodium hypochlorite for $3 \mathrm{~min}$ and then washed thoroughly with sterilized water. The disinfected stem pieces were dried between folds of sterile filter papers, then plated onto potato dextrose agar (PDA) medium supplemented with $0.2 \%$ yeast extract and incubated at $28 \pm 2{ }^{\circ} \mathrm{C}$ for $72 \mathrm{~h}$. Hyphal tip isolation technique was employed to obtain the fungus isolation in pure cultures. C. maydis was identified according to morphological and cultural features using the descriptions of Samra et al. (1963) and 
Ainsworth and James (1971). Five isolates of C. maydis were obtained from diseased maize plants and kept at $4{ }^{\circ} \mathrm{C}$ for further studies.

Inoculum preparation and determination of pathogenicity The isolates of $C$. maydis were grown into $250 \mathrm{ml}$ potato dextrose broth medium supplemented with $0.2 \%$ yeast extract in $500 \mathrm{ml}$ Erlenmeyer flasks. After sterilization, flasks were inoculated with each of the different isolates of $C$. maydis and then incubated at $28 \pm 2{ }^{\circ} \mathrm{C}$ for 2 weeks. The flasks were thoroughly shaken, and about $20 \mathrm{ml}$ of the suspension was poured into 1-1 glass bottles containing wet autoclaved crushed grain sorghum up to two thirds of its capacity. The inoculated glass bottles were then kept at $28 \pm 2{ }^{\circ} \mathrm{C}$ for 4 weeks. Pathogenicity test of the obtained isolates of $C$. maydis was conducted on a susceptible maize cultivar Baladi. Disinfested grain seeds were planted in pots $(30 \mathrm{~cm}$ in diameter) containing autoclaved clay loam soil $(6 \mathrm{~kg} / \mathrm{pot})$, infested with the inoculum of different isolates. Seed disinfestations were carried out by soaking seeds in 5\% sodium hypochlorite solution for $3 \mathrm{~min}$ and rinsed in sterile water. Pots and soil were treated 2 weeks before planting by autoclaving the soil and soaking the pots in $7 \%$ formalin solution for 3-5 min. Soil infestation was carried out 7 days before planting by mixing $180 \mathrm{~g}$ of inoculum to the soil in every pot and mixed thoroughly to ensure equal distribution of fungal propagates, followed by irrigation. Each pot was seeded with eight grain seeds of the Baladi cv., and plants were thinned to three plants per pot. Six pots were used for each isolate, and a non-inoculated treatment was used as control. Nitrogen fertilizer in the form of urea $(46 \% \mathrm{~N})$ was added at $500 \mathrm{mg} \mathrm{N} / \mathrm{kg}$ soil, 30 days after planting, and plants were irrigated when necessary. Percentage of dead plants due to late wilt infection was calculated 80 days after planting. Disease symptoms began to appear approximately 60 days after sowing. Pots were examined at weekly intervals thereafter and symptomatic plants removed when they were identified. Fungal isolates were recovered from internodes of symptomatic plants to demonstrate Koch's postulates. Among the tested isolates, the highest aggressive isolate was selected and used throughout the present study. The maize plants were harvested at 80 -day age by mulching the plants from the pots. The length of plants and their dry weight were determined. The harvested plants were dried at $70{ }^{\circ} \mathrm{C}$ till constant weight, and the dry weight per plant was recorded.

\section{Laboratory experiments} Antagonistic activity tests

Testing the antagonistic activities of Trichoderma spp. which uses either alone or in combination with $C$. vulgaris extracts against $C$. maydis was carried out. In the case of
Trichoderma spp. alone, the inhibitor effect of $T$. harzianum, T. koningii, $T$. viride, and $T$. virens against the growth of the most virulent isolate of $C$. maydis (isolate Cm3) was studied, using the method described by Bell et al. (1982). Petri plate containing PDA medium supplemented with $0.2 \%$ yeast extract was inoculated on one side with a 5-mm mycelial disc from a 7-day-old culture of the tested Trichoderma spp. The opposite side was inoculated with a disc of $C$. maydis, and the plates were incubated at $28 \pm 2{ }^{\circ} \mathrm{C}$. Plates inoculated with a disc of $C$. maydis alone were used as control. Four replicate plates were made for each test fungus as well as for the control. Colony radius of C. maydis was recorded when the control plates reached full growth. On the other hand, the effect of $C$. vulgaris water extracts on the antagonistic activity of Trichoderma spp. against C. maydis was carried out, using PDA plates amended with each of cool or hot extracts. Ten milliliters of each extract was filtered through a sterile $0.22-\mu \mathrm{m}$ Millipore filter directly into $190 \mathrm{ml}$ molten PDA. The medium was poured into sterile Petri plates and cooled at room temperature. The amended plates were used for dual culture test described before. Plates amended with cool extract, hot extract, and sterile distilled water and inoculated with a disc of $C$. maydis by itself were used as control. Four replicate plates were used for each treatment as well as for controls. Colony radius of $C$. maydis was recorded when the control plates reached full growth. The reduction in the growth of C. maydis was calculated, using the following formula:

$$
\text { Growth reduction }(\%)=[(C-T) / C] \times 100 \text {. }
$$

where $C$ is the average linear growth of $C$. maydis in control and $T$ is the average linear growth of $C$. maydis in biocontrol agent treatment.

\section{Development of Trichoderma-C. vulgaris extract formulation \\ Trichoderma spp. propagules}

Trichoderma harzianum, T. koningii, T. viride, and $T$. virens were grown on a PDA medium at $25 \pm 2{ }^{\circ} \mathrm{C}$ for 10 days. Afterwards, the mycelium with the spores was scraped from Petri plates and mixed with sterilized distilled water $(20 \mathrm{ml} /$ plate $)$ in a blender. The suspension was adjusted by a hemocytometer slide to $10^{8}$ propagates $/ \mathrm{ml}$.

\section{Preparation of $C$. vulgaris extracts}

Each of cool or hot extracts of $C$. vulgaris was prepared individually. Two hundred and fifty milliliters of each extract was filtered through a sterile $0.22-\mu \mathrm{m}$ Millipore filter directly into a 500-ml sterile conical flask. 


\section{Incorporation of Trichoderma spp. to C. vulgaris extracts} Propagule suspension $\left(10^{8}\right.$ propagates $\left./ \mathrm{ml}\right)$ of each of Trichoderma spp. were individually incorporated into sterilized $C$. vulgaris extracts under aseptic conditions at the rate of $10 \mathrm{ml}$ of suspension per $90 \mathrm{ml}$ extract and thoroughly shacked on a rotatory shaker at $70 \mathrm{rpm}$ for 6 h. Each Trichoderma-C. vulgaris extract was first stored at room temperature for 3 days to increase the initial population of Trichoderma spp., and then, they were applied.

\section{Population dynamics of Trichoderma spp. on C. vulgaris extracts}

The viability of Trichoderma spp. in C. vulgaris extracts was determined at $3,60,120,180,240,300$, and 360 days after storage (DAS) of room temperature $\left(27 \pm 2{ }^{\circ} \mathrm{C}\right)$. For the study of the potentiality of $7{ }^{\circ} \mathrm{C}$ storage conditions on the viability of the Trichoderma spp. in C. vulgaris extracts, they were first stored at room temperature for 3 days to increase the initial population of Trichoderma spp. Initial determination of population of Trichoderma spp. was made at 3 DAS at room temperature, and later samples were made at $60,120,180,240,300$, and 360 DAS at $7{ }^{\circ} \mathrm{C}$. Serial dilutions of formulation samples were used to determine the number of Trichoderma spp. propagules found on $C$. vulgaris extracts by the plate count technique using selective media (Johnson et al. 1960). Thus, the blended $1 \mathrm{ml}$ of formulation was transferred to bottles containing $99 \mathrm{ml}$ of sterilized distilled water under aseptic conditions. The bottles were shaken using a mechanical shaker for $15 \mathrm{~min}$. Serial dilutions of fresh suspension were prepared for each Trichoderma spp. in C. vulgaris extract sample under sterile conditions. A portion of $1.0 \mathrm{ml}$ formulation suspension from the dilution $10^{-4}$ was transferred to four sterile Petri plates. Rose Bengal streptomycin-selective medium was used for growing Trichoderma spp. colonies after 4 days of incubation at $25 \pm 2{ }^{\circ} \mathrm{C}$ (Metcalf 1997). This medium consisted of $2.0 \mathrm{~g}$ of $\left(\mathrm{NH}_{4}\right)_{2} \mathrm{SO}_{4}, 4.0 \mathrm{~g}$ of $\mathrm{KH}_{2} \mathrm{PO}_{4}, 6.0 \mathrm{~g}$ of $\mathrm{Na}_{2} \mathrm{HPO}_{4}, 0.2 \mathrm{~g}$ of Fe.SO $\mathrm{SO}_{4} 7 \mathrm{H}_{2} \mathrm{O}, 1 \mathrm{mg}$ of $\mathrm{CaCl}_{2}, 10 \mu \mathrm{g}$ of $\mathrm{H}_{3} \mathrm{BO}_{3}, 10 \mu \mathrm{g}$ of $\mathrm{MnSO}_{4}, 70 \mu \mathrm{g}$ of $\mathrm{Zn} \mathrm{SO}_{4}, 1 \mathrm{l}$ of distilled water, $20 \mathrm{~g}$ agar, and $5 \mathrm{~g}$ of cellulose powder (Sigma), adjusted to $\mathrm{pH} 4.0$ before autoclaving. After the medium cooled to $70{ }^{\circ} \mathrm{C}, 0.05 \mathrm{~g}$ of streptomycin sulfate and $0.016 \mathrm{~g}$ of rose Bengal were added.

\section{Greenhouse experiments}

A pot experiment was conducted to evaluate the influence of Trichoderma spp. treatments alone or formulated on C. vulgaris extracts on the incidence of maize late wilt as well as on growth parameters of maize plant in soil infected and non-infected with late wilt pathogen. The experiment was conducted in the summer season of 2016 at the greenhouse of Plant Nutrition Department,
Agriculture and Biological Division, National Research Centre, Egypt. The experiment was carried out in a randomized complete block design with four replicates. The most virulent isolate of $C$. maydis (isolate $\mathrm{Cm} 3$ ) was used. Seed disinfections were carried out by soaking seeds in 5\% sodium hypochlorite solution for $3 \mathrm{~min}$, rinsed in sterile water. Pots ( $30 \mathrm{~cm}$ in diameter) and soil were treated 2 weeks before planting by autoclaving the soil and soaking the pots in 7\% formalin solution for 3$5 \mathrm{~min}$. Soil infestation was carried out 7 days before planting by mixing $180 \mathrm{~g}$ of $C$. maydis inoculum to the soil in every pot $(6 \mathrm{~kg}$ soil/pot), followed by irrigation. Disinfected maize grains (Baladi cv.) were soaked in each treatment at the rate of $100 \mathrm{ml} / 100$ grain in $250-\mathrm{ml} \mathrm{Er}$ lenmeyer flasks. Control of grains was soaked in sterile distilled water only. Few drops of Tween- 80 were added to improve adhesive. Flasks were incubated at $25{ }^{\circ} \mathrm{C}$ on a rotary shaker at $70 \mathrm{rpm}$ for $6 \mathrm{~h}$ to allow treatment materials to adhere to seeds. After incubation, excess inoculum was removed and grains were left to air-dry for $30 \mathrm{~min}$ at room temperature and then immediately planted in the infected and/or un-infected potted soil (Ashour et al. 2013). Each pot was seeded with eight grain seeds, and the plants were thinned to three plants. The abovementioned treatments were applied to soil in the pots with irrigation water at three equal doses (30 $\mathrm{ml}$ per pot) each 10 days. Six pots were used for each treatment as well as control. Nitrogen fertilizer in the form of urea $(46 \% \mathrm{~N})$ was added at the rate of $500 \mathrm{mg} \mathrm{N} / \mathrm{kg}$ soil, 30 days after planting, and the plants were irrigated when necessary.

The following treatments were used in soil infected and non-infected with late wilt pathogen: (1): T. harzianum $\left(10 \times 10^{4}\right.$ propagates $/ \mathrm{ml}$ sterile distilled water), (2): T. koningii $\left(10 \times 10^{4}\right.$ propagates $/ \mathrm{ml}$ sterile distilled water), (3): T. viride $\left(10 \times 10^{4}\right.$ propagates $/ \mathrm{ml}$ sterile distilled water), (4): $T$. virens $\left(10 \times 10^{4}\right.$ propagates $/ \mathrm{ml}$ sterile distilled water), (5): T. harzianum $\left(10 \times 10^{4}\right.$ propagates/ $\mathrm{ml}$ cool water extract of C. vulgaris), (6): T. koningii $\left(10 \times 10^{4}\right.$ propagates $/ \mathrm{ml}$ cool water extract of C. vulgaris), (7): T. viride $\left(10 \times 10^{4}\right.$ propagates $/ \mathrm{ml}$ cool water extract of C. vulgaris), (8): T. virens $\left(10 \times 10^{4}\right.$ propagates $/ \mathrm{ml} \mathrm{cool} \mathrm{water} \mathrm{extract} \mathrm{of} \mathrm{C.} \mathrm{vulgaris),} \mathrm{(9):} \mathrm{T.} \mathrm{harzia-}$ num $\left(10 \times 10^{4}\right.$ propagates $/ \mathrm{ml}$ hot water extract of $C$. vulgaris), (10): T. koningii $\left(10 \times 10^{4}\right.$ propagates $/ \mathrm{ml}$ hot water extract of $C$. vulgaris), (11): T. viride $\left(10 \times 10^{4}\right.$ propagates $/ \mathrm{ml}$ hot water extract of $C$. vulgaris), (12): T. virens $\left(10 \times 10^{4}\right.$ propagates $/ \mathrm{ml}$ hot water extract of C. vulgaris), (13): Cooled water extract of C. vulgaris, (14): Heat water extract of C. vulgaris, (15): Control.

Percentage of dead plants due to late wilt infection was recorded 80 days after planting. Vegetative growth parameters, i.e., plant height and dry weight, were also recorded as previously described. 


\section{Field experiments}

The effect of Trichoderma spp. treatments alone or formulated on C. vulgaris extracts on the incidence of maize late wilt as well as on yield of maize plant was studied under field conditions in a disease nursery at Gemmiza Research Station, Plant Pathology Research Institute, Agriculture Research Center, Gharbia Governorate, Egypt, during the 2016 growing season. This nursery was infested artificially with the four clonal lineages of C. maydis found in Egypt that causes late wilt of maize and commonly used in Egyptian maize breeding programs (Zeller et al. 2002). Maize grains cv. Baladi were used in this study. The abovementioned treatments in greenhouse were involved in field experiments. Disinfected maize grains (Baladi cv.) were soaked in each treatment at the rate of $100 \mathrm{ml} / 100$ grain. Control grains were soaked in sterile distilled water only. Randomized complete block arrangement in three replicate plots was used. Each replicate included three ridges of $4.5-\mathrm{m}$ length and $0.7-\mathrm{m}$ width for each ridge, i.e., the experimental plot area was $3.15 \mathrm{~m}^{2}$. Thirteen maize plants for each treatment were used in each replicate. Grains were sown in holes (five holes/ridge with three grains/hole); thereafter, they were thinned to one plant/hole. The abovementioned treatments were also applied before irrigation with water at three equal doses $(10 \mathrm{ml}$ per hole) each 15 days. Irrigation, recommended fertilizer levels, and agronomical practices were used as usual. Disease incidence of late wilt as infection percentage was recorded 110 days after sowing. Quantitative maize yield and qualitative maize yield, i.e., ear length, ear diameter, no. of rows per ear, no. of kernels per row, no. of kernels per ear, and 100-kernel weight, were evaluated during harvest period.

\section{Statistical analysis}

Statistical analysis of data was conducted, using SPSS software version 14.0. Percent data of disease incidence were statistically analyzed after arcsine square root transformation; however, untransformed data are presented. Analysis of variance was determined, and the mean values were compared by Duncan's multiple range test at $P<0.05$.

\section{Results and discussion}

\section{Chemical analysis of Chlorella extract}

Chlorella as the freshwater microalgae is considered the most useful green algae (Liu et al. 2016). It contains lipopolysaccharides which differ from Gram-negative bacteria because chlorella has no endotoxins (Stewart et al. 2006). Dried biomass total sugars of C. vulgaris represented $9.7 \%+0.12$. Out of this content, soluble sugar content, which is determined by weight, varied between the two fractions (cold and hot extracts). Mostly, hot extract represented the maximum figure of total sugars (16.42 and 12.31\%) of total carbohydrates. GLC analysis of each fraction is listed in Table 1. The most abundant sugars are galactose, mannose, rhamnose, and glucose that reached more than $10 \%$ of total carbohydrates. Concerning such chemical structure, growth conditions (outdoor mass production) markedly affected it to form a rigid cell wall. This is in agreement with Cheng et al. (2011), who described that the chemical composition of the cell wall in Chlorella variabilis NC64A was impacted by cultivation conditions such as uronic acid, neutral sugar, and amino sugar in the cell wall when cultivated in diverse sources and concentrations of nitrogen. Unbending cell walls of Chlorella species contain mannose as a major sugar component. Numerous polysaccharides contained phosphate, carboxylic, and/or ester sulfuric groups in the molecular structure (Nelson and Cox 2008). These polysaccharides, in a pure form, are presently the most commercial protectors for plants against pathogens (Stadnik and Freitas 2014).

\section{C. maydis isolation}

Five isolates of $C$. maydis obtained from infected maize plants were studied on a susceptible cultivar Baladi. For recording infection percentage by late wilt, typical disease symptoms formerly described by Samra et al. (1963) were observed on infected plants. Koch's postulates were demonstrated for all C. maydis isolates recovered from infected maize plants in the field. All $C$. maydis isolates were examined for pathogenicity toward maize plants in greenhouse. Results in Table 2 showed that the five isolates were capable of causing late wilt disease and were potentially pathogenic in greenhouse assay system. Non-inoculated plants (control) did not develop late wilt symptoms. Data also showed that the tested C. maydis isolates were statistically differed in their aggressiveness toward maize plants where disease percentages varied between 65.0 and $78.2 \%$, at 110 days after sowing. The most virulent isolate was $\mathrm{Cm} 3$,

Table 1 Intercellular saccharide content (\% dw from total carbohydrates) of Chlorella vulgaris cool and hot extract

\begin{tabular}{lll}
\hline Saccharide & \multicolumn{2}{c}{ \% content (dry weight from total carbohydrates) } \\
\cline { 2 - 3 } & Cool & Hot \\
\hline Galactose & 25.5 & 26.30 \\
Mannose & 16.3 & 11.90 \\
Rhamnose & 14.5 & 18.20 \\
Glucose & 13.4 & 10.60 \\
Arabinose & 09.7 & 10.70 \\
Xylose & 06.6 & 08.90 \\
Fructose & 02.9 & 02.96 \\
Ribose & 02.8 & 02.03 \\
\hline
\end{tabular}


followed by $\mathrm{Cm} 4$, while the isolates $\mathrm{Cm} 1, \mathrm{Cm} 2$, and $\mathrm{Cm} 5$ were the least ones. These findings are in agreement with those obtained by Ali (2000). García-Carneros et al. (2012) found that the initial incidence of late wilt symptoms in maize plants depends on the isolate of $C$. maydis and on the maize variety and the final severity of the aboveground symptoms only depends on the fungal isolate. The pathogenic differences among the tested isolates may be due to the genetic diversity among them. Zeller et al. (2002) found that the four phylogenetic lineages of $C$. maydis differed in their virulence and competitiveness toward maize plants grown under greenhouse conditions. A highly negative correlation was observed among infection percentages incited by $C$. maydis isolates and each of plant height and dry weight of maize plants after 110 days. These results are in harmony with the findings of Alhanshoul (2015) who reported that infection with $C$. maydis isolates slightly reduced seed germination, plant height, and dry weight of plants.

\section{Antagonistic activity of Trichoderma spp. and C. vulgaris extracts against $C$. maydis}

Four Trichoderma species were tested alone or in combination with $C$. vulgaris extracts for antagonistic activity against $C$. maydis, using the dual culture technique (Table 3). All Trichoderma species treatments inhibited the growth of $C$. maydis in dual culture compared to control. Data indicated that $T$. harzianum, T. viride, T.virens, and T. koningii reduced the growth of C. maydis by $63.3,50.0,75.6$, and $70.9 \%$, respectively, when used alone, while the reduction attained to 81.1 and 80.0, 61.1 and 60.4, 87.6 and 88.0, and 85.8 and $86.9 \%$ when they were used in combination with cool and hot extracts of C. vulgaris, respectively. Trichoderma species showed rapid growth, outcompeting the pathogen for space and nutrients. After the Trichoderma species growth meets the $C$. maydis colony, it would inhibit further growth of the hyphal tips of the pathogen and

Table 2 Virulence of Cephalosporium maydis isolates on maize cv. Baladi under greenhouse conditions

\begin{tabular}{|c|c|c|c|}
\hline \multirow[t]{2}{*}{ Isolate } & \multirow{2}{*}{$\begin{array}{l}\text { Disease } \\
\text { incidence } \\
(\%)\end{array}$} & \multicolumn{2}{|l|}{ Plant's vigor } \\
\hline & & Plant height $(\mathrm{cm})$ & Plant dry weight (g) \\
\hline C. maydis (Cm1) & $67.2 \pm 0.37 c$ & $66.2 \pm 0.37 \mathrm{bc}$ & $29.2 \pm 0.48 b$ \\
\hline C. maydis (Cm2) & $65.0 \pm 1.00 \mathrm{~d}$ & $64.6 \pm 0.40 c$ & $27.0 \pm 0.31 c$ \\
\hline C. maydis (Cm3) & $78.2 \pm 0.37 a$ & $59.4 \pm 0.60 d$ & $23.6 \pm 0.50 d$ \\
\hline C. maydis (Cm4) & $74.4 \pm 1.16 b$ & $66.8 \pm 0.37 b$ & $28.0 \pm 0.31 b c$ \\
\hline C. maydis (Cm5) & $67.6 \pm 0.60 c$ & $66.6 \pm 0.24 b c$ & $26.8 \pm 0.37 c$ \\
\hline Control & 00.0 & $83.4 \pm 1.40 a$ & $34.8 \pm 0.20 a$ \\
\hline
\end{tabular}

The presented data are the mean \pm standard errors, and the letters show significance at $P \leq 0.05$ caused the die back rapidly of fungal colony. Trichoderma spp. produce their biocontrol action against fungal phytopathogens either indirectly by competing for nutrients and space or indirectly by mechanisms such as antibiosis and mycoparasitism (Benítez et al. 2004). The additive effect of microalgae extracts to Trichoderma species in dual culture may be due to its bio-stimulators and immunity effects. These microalgae produce growth-promoting regulators, vitamins, amino acids, polypeptides, and polymers such as exo-polysaccharides (Singh et al. 2005). Wake et al. (1992) reported that freshwater microalgae as $C$. vulgaris contain high amounts of micro- and macronutrients (metabolites) as proteins and carbohydrates. These bio-fertilizers enhance Trichoderma growth and subsequently its antagonistic agent production. On the other hand, the reduction of $C$. maydis growth caused by $C$. vulgaris extracts may be due to the low saprophytic behavior of $C$. maydis (Sabet et al. 1970) that minimizes its growth on PDA amended with algae extracts.

\section{Population dynamics of Trichoderma spp. on C. vulgaris extracts}

The results of the effect of cool and heat extracts of $C$. vulgaris-based liquid formulations on the population dynamics of Trichoderma spp. at room temperature indicated that the algae extracts supported the highest population of Trichoderma spp. during the DAS sampled

Table 3 Antagonistic activity of Trichoderma spp. alone or in combination with Chlorella vulgaris extract against the linear growth of Cephalosporium maydis

\begin{tabular}{lll}
\hline Treatment & \multicolumn{2}{l}{ Linear growth and growth reduction of C. maydis } \\
\cline { 2 - 3 } & Linear growth (cm) & Reduction (\%) \\
\hline T. harzianum (Th) & $3.30 \pm 0.20 \mathrm{~d}$ & 63.3 \\
T. viride (Tv) & $4.50 \pm 0.15 \mathrm{C}$ & 50.0 \\
T. virens (Tvs) & $2.20 \pm 0.12 \mathrm{f}$ & 75.6 \\
T. koningii (Tk) & $2.62 \pm 0.05 \mathrm{e}$ & 70.9 \\
Cool extract + Th & $1.70 \pm 0.12 \mathrm{~g}$ & 81.1 \\
Cool extract + Tv & $3.50 \pm 0.15 \mathrm{~d}$ & 61.1 \\
Cool extract + Tvs & $1.12 \pm 0.04 \mathrm{~h}$ & 87.6 \\
Cool extract + Tk & $1.28 \pm 0.03 \mathrm{~h}$ & 85.8 \\
Hot extract + Th & $1.80 \pm 0.12 \mathrm{~g}$ & 80.0 \\
Hot extract + Tv & $3.56 \pm 0.16 \mathrm{~d}$ & 60.4 \\
Hot extract + Tvs & $1.08 \pm 0.04 \mathrm{~h}$ & 88.0 \\
Hot extract + Tk & $1.18 \pm 0.04 \mathrm{~h}$ & 86.9 \\
Cool extract & $7.88 \pm 0.08 \mathrm{~b}$ & 12.4 \\
Hot extract & $7.64 \pm 0.17 \mathrm{~b}$ & 15.1 \\
Control & $9.00 \pm 0.00 \mathrm{a}$ & 00.0 \\
\hline
\end{tabular}

The presented data are the mean \pm standard errors, and the letters show significance at $P \leq 0.05$ 
(data not shown). The population of Trichoderma spp. found on cool and heat extracts of $C$. vulgaris followed a fluctuating trend with the DAS sampled. The initial population (3 days) of Trichoderma spp. was increased at 60 DAS. At 120 DAS, the population recovery in all the Trichoderma spp. was significantly increased. Thereafter, during the period of 180 to 300 DAS, the population of Trichoderma spp. was declined progressively, and at 360 DAS, a significant reduction of more than four- to ninefold was recorded. The results of the population dynamics of Trichoderma spp. in extracts of C. vulgaris, when the liquid formulations were stored at $7{ }^{\circ} \mathrm{C}$, showed that there was a slow and progressive decline of the antagonist populations in the bioformulations from 120 DAS to 180, 240, 300 , and 360 DAS. Still, the population recovered was much greater as compared to that recorded during the same period under room temperature storage conditions. These formulations maintained the capacity of Trichoderma spp. to inhibit growth of the pathogen for up to 1 year when stored at both room temperature or at $7{ }^{\circ} \mathrm{C}$ (data not shown).

\section{Efficiency of treatments on maize late wilt disease}

After obtaining positive reaction of using microalgae cool or hot water extracts with Trichoderma spp. in controlling of $C$. maydis, the experiments were applied under greenhouse and field conditions. This confirms the efficiency of applying $C$. vulgaris extracts as growth promoters and biocontrol agents. Under greenhouse conditions, data presented in Table 4 showed that seed + soil treatment with Trichoderma spp. either alone or in combination with $C$. vulgaris extracts significantly reduced the infection percentage with late wilt disease compared to check treatment (73.4\% infection) under artificial soil infestation. Treatment with Trichoderma spp. formulated on C. vulgaris extracts gave the highest effect in reducing infection percentages compared to Trichoderma spp. alone. Among the Trichoderma spp., $T$. virens formulated on hot extract of $C$. vulgaris, followed by $T$. virens formulated on cool extract and $T$. koningii formulated on cool extract, were the effective treatments in reducing infection percentages, being 72.1, 68.3 , and $67.6 \%$ reduction in disease incidence, respectively. Other Trichoderma spp. treatments used either alone or in combination with $C$. vulgaris extracts showed moderate effect. Treatment with C. vulgaris extracts alone showed the lowest effect in reducing the infection percentage with late wilt.

In the field experiment, treatment of seed and soil with Trichoderma spp. either alone or in combination with $C$. vulgaris extracts showed significant reduction in maize infection with late wilt compared to check plants (47.6\% infection) as presented in Table 4. The combination treatments of Trichoderma spp. with $C$. vulgaris
Table 4 Effect of Trichoderma spp. alone or in combination with Chlorella vulgaris extract on the incidence of late wilt of maize grown under greenhouse and field conditions

\begin{tabular}{lll}
\hline Treatment & \multicolumn{2}{l}{ Late wilt incidence (\%) } \\
\cline { 2 - 3 } & Greenhouse experiment & Field experiment \\
\hline T. harzianum (Th) & $45.2 \pm 0.86 \mathrm{c}$ & $31.8 \pm 0.48 \mathrm{c}$ \\
T. viride (Tv) & $37.6 \pm 0.51 \mathrm{~d}$ & $28.6 \pm 0.50 \mathrm{~d}$ \\
T. virens (Tvs) & $33.6 \pm 0.24 \mathrm{e}$ & $23.8 \pm 0.37 \mathrm{e}$ \\
T. koningii (Tk) & $30.2 \pm 0.20 \mathrm{f}$ & $24.6 \pm 0.24 \mathrm{e}$ \\
Cool extract + Th & $30.0 \pm 0.31 \mathrm{f}$ & $20.8 \pm 0.48 \mathrm{f}$ \\
Cool extract + Tv & $27.6 \pm 0.24 \mathrm{~g}$ & $16.4 \pm 0.40 \mathrm{~g}$ \\
Cool extract + Tvs & $23.2 \pm 0.20 \mathrm{~h}$ & $12.8 \pm 0.48 \mathrm{~h}$ \\
Cool extract + Tk & $23.8 \pm 0.37 \mathrm{~h}$ & $12.4 \pm 0.40 \mathrm{~h}$ \\
Hot extract + Th & $27.6 \pm 0.24 \mathrm{~g}$ & $17.6 \pm 0.40 \mathrm{~g}$ \\
Hot extract + Tv & $30.0 \pm 0.31 \mathrm{f}$ & $19.6 \pm 0.74 \mathrm{f}$ \\
Hot extract + Tvs & $21.0 \pm 0.31 \mathrm{i}$ & $12.4 \pm 0.40 \mathrm{~h}$ \\
Hot extract + Tk & $22.4 \pm 0.24 \mathrm{hi}$ & $12.4 \pm 0.40 \mathrm{~h}$ \\
Cool extract & $57.4 \pm 0.81 \mathrm{~b}$ & $46.8 \pm 0.48 \mathrm{a}$ \\
Hot extract & $57.2 \pm 0.37 \mathrm{~b}$ & $43.8 \pm 0.20 \mathrm{~b}$ \\
Control & $73.4 \pm 1.66 \mathrm{a}$ & $47.6 \pm 0.24 \mathrm{a}$ \\
\hline
\end{tabular}

The presented data are the mean \pm standard errors, and the letters show significance at $P \leq 0.05$

extracts caused more reduction in maize late wilt compared to the individual treatments of Trichoderma spp. or $C$. vulgaris extracts. However, the combined treatment of $C$. vulgaris extract with $T$. virens and/or $T$. koningii gave the highest reduction in late wilt incidence, being 73.1 and $74.0 \%$, respectively, in comparison to treatment with $T$. virens or $T$. koningii each alone, being 50.0 and $48.3 \%$ reduction, respectively. The lowest reduction in disease incidence was recorded by $C$. vulgaris extract treatments only (being 1.7 and $8.0 \%$ reduction). The antagonistic effect of Trichoderma strains against soil-borne fungi was recently emphasized by Elshahawy et al. (2017b). The reported data describe, for the first time, control of the pathogen, using Trichoderma strains in Egypt. The ability of Trichoderma strains to inhibit $C$. maydis pathogen is noteworthy since the suppression obtained is a result of seed + soil treatment. Addition of Trichoderma strains with $C$. vulgaris extracts increased their effect against $C$. maydis. These results suggest that C. vulgaris extracts stimulate the inhibitory activity of Trichoderma strains. This may be due to that $C$. vulgaris extracts are considered as absorbed agents into plants for increasing of disease and stress resistance (Abd El-Motty et al. 2010). Amendment of Trichoderma strains with $C$. vulgaris extracts could increase the plant protection by supporting the growth of Trichoderma strains and stimulating the useful metabolite production which may help antagonistic activity. Degani et al. 
(2015) reported that many plant growth promoters such as hormones, auxin (indole-3-acetic acid), and cytokinin (kinetin) were produced by higher levels, when using $C$. vulgaris extracts, suppressing C. maydis in culture media and in a detached root assay.

\section{Efficiency of treatments on maize growth in greenhouse and on maize yield in field Greenhouse experiment}

Data presented in Table 5 showed that the seed + soil treatment with Trichoderma spp., either alone or in combination with $C$. vulgaris extract, significantly promoted plant growth compared to check treatment, whether grown in infested or un-infested soil. Moreover, Trichoderma spp. formulated with $C$. vulgaris extract caused significant increment in maize growth parameters compared to treatment of Trichoderma spp. alone. Regarding plant height, data indicated that all treatments significantly increased plant height in either infested or un-infested soil, being 60.4 and $78.41 \mathrm{~cm}$, respectively. Combined treatments of Trichoderma spp. and microalgae extracts increased plant height when plants were grown, either in infested or in un-infested soil compared to individual treatments. However, the combined treatment of $T$. virens and T. koningii with cool extract of $C$. vulgaris caused the highest plant heights when plants were grown either in infested soil $(103.6$ and $106.4 \mathrm{~cm})$ or in un-infested soil $(119.6$ and $118.0 \mathrm{~cm})$ in comparison to the individual treatments. The combination treatments of $T$. virens and T. koningii with hot extract of $C$. vulgaris, followed the previous treatments in their effect on plant height, being 102.2 and $102.8 \mathrm{~cm}$ for plants grown in infested soil as well as 115.8 and $116.4 \mathrm{~cm}$ when grown in un-infested soil, respectively. Other treatments showed moderate effects. In concern to plant dry weight, results presented in Table 4 showed that all treatments recorded significant increment in dry weight of maize plants grown either in infested or in un-infested soil compared to check plants (24.2 and 33.8 g, respectively). Likewise, combined treatments between Trichoderma spp. and microalgae extracts significantly increased dry weight of plants in comparable with the individual treatments for plants grown either in infested or in un-infested soil. However, the combined treatments of $T$. virens and T. koningii with cool extract of C. vulgaris gave the highest dry weight of plants grown either in infested soil $(49.4$ and 50.6 g, respectively) or in un-infested soil (58.4 and $58.4 \mathrm{~g}$, respectively). The treatment of Trichoderma spp. and algae extracts had moderate effect on plant dry weight either grown in infested soil or in un-infested soil. The effect of bio-fertilization, using microalgae extracts, was suggested for increasing the growth parameters of many plants. This is likely due to the biochemical composition of microalgae extracts which are rich in essential nutrients for plant growth as nitrate reductase, nitrogenase, and minerals. The impact of foliar feeding by water extracts of C. vulgaris on growth, nutrient levels, and yield

Table 5 Effect of Trichoderma spp. alone or in combination with Chlorella vulgaris extract on maize plant growth characters under infested and un-infested soil with Cephalosporium maydis

\begin{tabular}{|c|c|c|c|c|}
\hline \multirow[t]{3}{*}{ Treatment } & \multicolumn{4}{|l|}{ Plant's vigor } \\
\hline & \multicolumn{2}{|l|}{ Un-infested soil } & \multicolumn{2}{|l|}{ Infested soil } \\
\hline & Plant height (cm) & Plant dry weight (g) & Plant height (cm) & Plant dry weight (g) \\
\hline T. harzianum (Th) & $90.4 \pm 0.24 j$ & $38.4 \pm 0.24 h$ & $83.6 \pm 0.24 j$ & $33.4 \pm 0.24 i$ \\
\hline T. viride (Tv) & $88.2 \pm 0.20 \mathrm{k}$ & $36.4 \pm 0.24 i$ & $84.0 \pm 0.54 j$ & $31.4 \pm 0.24 j$ \\
\hline T. virens (Tvs) & $91.6 \pm 0.24 i$ & $40.4 \pm 0.24 \mathrm{~g}$ & $88.4 \pm 0.24 h$ & $33.8 \pm 0.20 h i$ \\
\hline T. koningii (Tk) & $93.4 \pm 0.24 \mathrm{~g}$ & $41.4 \pm 0.24 f$ & $87.4 \pm 0.24 i$ & $34.2 \pm 0.20 h$ \\
\hline Cool extract + Th & $103.4 \pm 0.24 d$ & $50.2 \pm 0.20 c$ & $100.6 \pm 0.40 d$ & $43.4 \pm 0.24 d$ \\
\hline Cool extract + Tv & $100.0 \pm 0.54 f$ & $50.4 \pm 0.24 c$ & $100.8 \pm 0.37 d$ & $44.4 \pm 0.24 c$ \\
\hline Cool extract + Tvs & $119.6 \pm 0.24 a$ & $58.4 \pm 0.24 a$ & $103.6 \pm 0.24 b$ & $49.4 \pm 0.24 b$ \\
\hline Cool extract + Tk & $118.0 \pm 0.31 b$ & $58.4 \pm 0.24 a$ & $106.4 \pm 0.24 a$ & $50.6 \pm 0.24 a$ \\
\hline Hot extract + Th & $103.8 \pm 0.20 d$ & $50.8 \pm 0.37 c$ & $96.0 \pm 0.31 f$ & $42.6 \pm 0.24 \mathrm{e}$ \\
\hline Hot extract + Tv & $101.4 \pm 0.40 \mathrm{e}$ & $50.4 \pm 0.24 c$ & $97.2 \pm 0.20 \mathrm{e}$ & $43.0 \pm 0.31 \mathrm{de}$ \\
\hline Hot extract + Tvs & $115.8 \pm 0.20 c$ & $55.4 \pm 0.24 b$ & $102.2 \pm 0.20 c$ & $49.4 \pm 0.24 b$ \\
\hline Hot extract + Tk & $116.4 \pm 0.24 c$ & $55.6 \pm 0.24 b$ & $102.8 \pm 0.20 c$ & $49.6 \pm 0.24 b$ \\
\hline Cool extract & $93.6 \pm 0.24 \mathrm{~g}$ & $44.4 \pm 0.24 d$ & $88.6 \pm 0.24 h$ & $35.0 \pm 0.44 \mathrm{~g}$ \\
\hline Hot extract & $92.6 \pm 0.24 h$ & $43.4 \pm 0.24 \mathrm{e}$ & $90.6 \pm 0.24 \mathrm{~g}$ & $37.6 \pm 0.24 f$ \\
\hline Control & $78.4 \pm 0.241$ & $33.8 \pm 0.37 j$ & $60.4 \pm 0.24 k$ & $24.2 \pm 0.20 \mathrm{k}$ \\
\hline
\end{tabular}

The presented data are the mean \pm standard errors, and the letters show significance at $P \leq 0.05$ 
of wheat (Triticum aestivum L.) var. Giza 69 was investigated by Shabaan (2010). They reported that 50\% $(v / v)$ microalgae extracts foliar spray, after 25 days of sowing, increased plant growth and grain weight by 140 and $40 \%$, respectively. The present study showed that the addition of $C$. vulgaris water extracts to the culture medium or soil increased the fresh and dry weight of maize seedlings. Abd El-Motty et al. (2010) reported that spraying of 2\% algae combined with $0.2 \%$ yeast on Keitte mango trees once at full bloom had improved nitrogen, potassium, and boron contents in the leaves. In this respect, Taha and Youssef (2015) reported a significant increase of growth mass as well as content of phosphorous, potassium, and chlorophyll of maize plants grown in soil treated with green microalgae strains of Chlorella.

\section{Field experiment}

Following the greenhouse experiments, field experiments were the advanced confirmation for the aim of this work. Data in Tables 6 and 7 showed that seed + soil treatment with Trichoderma spp. either alone or in combination with C. vulgaris extracts significantly improved crop production and ear characters compared to check plants. Moreover, combination of Trichoderma spp. with C. vulgaris extracts caused markedly an increase in maize yield parameters compared to the individual treatments. All treatments increased the yield of maize plants. The treatment of $T$. virens in combination with cool and hot extracts of $C$. vulgaris caused the highest of ears, weight of grains, and weight of grains/plant, being 4338.0 and
4369.3, 2227.0 and 2229.4, and 348.0 and 352.1, respectively, compared to the control, being 1165.7, 893.1, and 195.0 g. In contrast, plants treated with cool extract of C. vulgaris alone produced the lowest yield compared to the other treatments (Table 6).

The same trend was observed in regard to 100-kernel weight (Table 6). The highest weight was recorded in the case of combination treatments of Trichoderma spp. with $C$. vulgaris extracts. The lowest 100 grain weight was obtained by the control treatment $(28.34 \mathrm{~g})$. Data in Table 6 also indicated insignificant differences among treatments concerning ear parameters of ear diameter, ear length, no. of rows per ear, and no. of kernels per row. All treatments increased ear parameters compared to check plants. Combined treatments of Trichoderma spp. with $C$. vulgaris extracts caused the highest ear parameters. Microalgae extracts containing many nutrients as $\mathrm{N}, \mathrm{P}, \mathrm{Ca}, \mathrm{K}, \mathrm{S}$, and $\mathrm{Mg}$, as well as some trace elements as $\mathrm{Fe}, \mathrm{Zn}, \mathrm{Mn}, \mathrm{Mo}, \mathrm{Co}$, and $\mathrm{Cu}$ and some growth regulators, vitamins, and polyamines, were applied to stimulate vegetative growth, nutritional levels, yield, and fruit quality of different orchard as well as vineyards (Abd El-Migeed et al. 2004 and Spinelli et al. 2009).

\section{Conclusions}

Trichoderma spp. are one of the proven biological control agents. In the present study, the antagonism of Trichoderma strains in combination with $C$. vulgaris extracts increased the efficiency of controlling the maize late wilt disease. Treatments also increased maize plant growth and yield. It is suggested that extracellular

Table 6 Effect of Trichoderma spp. alone or in combination with Chlorella vulgaris extract on yield of maize plants grown under field conditions

\begin{tabular}{llll}
\hline Treatment & \multicolumn{2}{l}{ Maize plants grown under field conditions } & Av. weight of grains/plant (g) \\
\cline { 2 - 4 } & Av. weight of ears/plot (g) & Av. weight of grains/plot (g) & $227.0 \pm 1.77 \mathrm{de}$ \\
\hline T. harzianum (Th) & $2780.0 \pm 14.4 \mathrm{f}$ & $1796.7 \pm 2.66 \mathrm{~g}$ & $208.0 \pm 1.086 \mathrm{e}$ \\
T. viride (Tv) & $2716.0 \pm 10.5 \mathrm{f}$ & $1688.6 \pm 0.32 \mathrm{~h}$ & $235.4 \pm 1.70 \mathrm{cde}$ \\
T. virens (Tvs) & $3243.3 \pm 12.3 \mathrm{~d}$ & $2059.7 \pm 3.80 \mathrm{c}$ & $226.8 \pm 2.88 \mathrm{de}$ \\
T. koningii (Tk) & $3068.0 \pm 13.0 \mathrm{e}$ & $2046.9 \pm 0.85 \mathrm{~d}$ & $310.4 \pm 32.67 \mathrm{ab}$ \\
Cool extract + Th & $3510.0 \pm 8.6 \mathrm{c}$ & $1934.3 \pm 6.28 \mathrm{e}$ & $261.3 \pm 25.43 \mathrm{bcde}$ \\
Cool extract + Tv & $3495.0 \pm 22.9 \mathrm{c}$ & $1830.4 \pm 3.35 \mathrm{f}$ & $348.0 \pm 38.19 \mathrm{a}$ \\
Cool extract + Tvs & $4338.0 \pm 10.3 \mathrm{a}$ & $2227.0 \pm 1.26 \mathrm{ab}$ & $327.4 \pm 37.52 \mathrm{ab}$ \\
Cool extract + Tk & $4046.0 \pm 19.6 \mathrm{~b}$ & $2220.2 \pm 0.29 \mathrm{~b}$ & $302.8 \pm 34.99 \mathrm{abc}$ \\
Hot extract + Th & $3520.0 \pm 13.2 \mathrm{c}$ & $1929.0 \pm 3.95 \mathrm{e}$ & $296.6 \pm 32.12 \mathrm{abcd}$ \\
Hot extract + Tv & $3490.0 \pm 21.7 \mathrm{c}$ & $1827.0 \pm 5.59 \mathrm{f}$ & $352.1 \pm 38.86 \mathrm{a}$ \\
Hot extract + Tvs & $4369.3 \pm 27.2 \mathrm{a}$ & $2229.4 \pm 2.57 \mathrm{a}$ & $311.6 \pm 35.74 \mathrm{ab}$ \\
Hot extract + Tk & $4040.3 \pm 5.6 \mathrm{~b}$ & $2224.2 \pm 1.62 \mathrm{ab}$ & $208.0 \pm 0.68 \mathrm{e}$ \\
Cool extract & $2003.3 \pm 26.0 \mathrm{~h}$ & $1500.6 \pm 0.36 \mathrm{i}$ & $205.6 \pm 0.16 \mathrm{e}$ \\
Hot extract & $2185.3 \pm 14.6 \mathrm{~g}$ & $1503.0 \pm 0.61 \mathrm{i}$ & $195.0 \pm 1.11 \mathrm{e}$
\end{tabular}

The presented data are the mean \pm standard errors, and the letters show significance at $P \leq 0.05$ 
Table 7 Effect of Trichoderma spp. alone or in combination with Chlorella vulgaris extract on average parameters of yield component of maize plants grown under field conditions

\begin{tabular}{|c|c|c|c|c|c|}
\hline \multirow[t]{2}{*}{ Treatment } & \multicolumn{5}{|c|}{ Average parameters of yield component of maize plants grown under field conditions } \\
\hline & Av. ear length $(\mathrm{cm})$ & Av. ear diameter (cm) & No. of row/ear & No. of kernel/row & 100 kernel weight $(\mathrm{g})$ \\
\hline T. harzianum (Th) & $22.59 \pm 0.05 e$ & $4.11 \pm 0.03 e$ & $12.8 \pm 0.33 a b c$ & $40.2 \pm 0.13 \mathrm{~g}$ & $32.29 \pm 0.07 f g$ \\
\hline T. viride (Tv) & $22.31 \pm 0.08 f$ & $4.26 \pm 0.03 \mathrm{~cd}$ & $12.4 \pm 0.26 c$ & $40.7 \pm 0.15 f g$ & $32.14 \pm 0.09 \mathrm{~g}$ \\
\hline T. virens (Tvs) & $22.58 \pm 0.10 \mathrm{e}$ & $4.28 \pm 0.03 \mathrm{bcd}$ & $12.4 \pm 0.26 \mathrm{c}$ & $41.6 \pm 0.16 \mathrm{e}$ & $32.78 \pm 0.08$ defg \\
\hline T. koningii (Tk) & $22.79 \pm 0.02 \mathrm{~cd}$ & $4.35 \pm 0.01 a$ & $13.0 \pm 0.33 a b c$ & $41.0 \pm 0.25 \mathrm{ef}$ & $32.53 \pm 0.18 \mathrm{efg}$ \\
\hline Cool extract + Th & $22.99 \pm 0.01 a$ & $4.35 \pm 0.01 a$ & $13.2 \pm 0.32 \mathrm{abc}$ & $44.6 \pm 0.22 b c$ & $33.47 \pm 0.13 \mathrm{bcd}$ \\
\hline Cool extract + Tv & $22.90 \pm 0.02 \mathrm{abc}$ & $4.24 \pm 0.01 d$ & $13.0 \pm 0.33 \mathrm{abc}$ & $43.5 \pm 0.16 d$ & $33.32 \pm 0.14 \mathrm{cde}$ \\
\hline Cool extract + Tvs & $22.85 \pm 0.02 b c$ & $4.36 \pm 0.01 a$ & $13.6 \pm 0.26 a$ & $45.0 \pm 0.25 a b$ & $33.52 \pm 0.17 \mathrm{abcd}$ \\
\hline Cool extract + Tk & $22.94 \pm 0.02 a b$ & $4.36 \pm 0.01 a$ & $13.4 \pm 0.30 a b$ & $45.0 \pm 0.21 \mathrm{ab}$ & $33.56 \pm 0.15 a b c d$ \\
\hline Hot extract + Th & $22.94 \pm 0.02 \mathrm{ab}$ & $4.24 \pm 0.01 d$ & $13.0 \pm 0.33 a b c$ & $44.7 \pm 0.26 b c$ & $33.76 \pm 0.06 a b c$ \\
\hline Hot extract + Tv & $22.85 \pm 0.02 b c$ & $4.24 \pm 0.01 d$ & $12.8 \pm 0.32 \mathrm{abc}$ & $44.3 \pm 0.15 c$ & $33.02 \pm 0.09 \mathrm{cdef}$ \\
\hline Hot extract + Tvs & $22.93 \pm 0.03 a b$ & $4.34 \pm 0.03 a b$ & $13.6 \pm 0.26 a$ & $45.5 \pm 0.22 a$ & $34.23 \pm 0.01 a b$ \\
\hline Hot extract + Tk & $22.97 \pm 0.02 a b$ & $4.32 \pm 0.02 \mathrm{abc}$ & $12.6 \pm 0.30 \mathrm{bc}$ & $45.2 \pm 0.24 a b$ & $34.35 \pm 0.12 \mathrm{a}$ \\
\hline Cool extract & $22.66 \pm 0.03 \mathrm{de}$ & $4.24 \pm 0.01 d$ & $12.4 \pm 0.26 c$ & $40.4 \pm 0.16 \mathrm{fg}$ & $30.19 \pm 0.11 \mathrm{~h}$ \\
\hline Hot extract & $22.78 \pm 0.03 \mathrm{~cd}$ & $4.26 \pm 0.01 \mathrm{~cd}$ & $12.4 \pm 0.26 c$ & $40.5 \pm 0.16 \mathrm{fg}$ & $29.66 \pm 0.39 h$ \\
\hline Control & $22.37 \pm 0.08 f$ & $3.86 \pm 0.01 f$ & $10.4 \pm 0.26 d$ & $33.6 \pm 0.45 h$ & $28.34 \pm 1.04 i$ \\
\hline
\end{tabular}

The presented data are the mean \pm standard errors, and the letters show significance at $P \leq 0.05$

saccharides content of $C$. vulgaris extracts enhanced the growth and adhesion of Trichoderma spp. which promoted plant growth through increasing antifungal activity.

\section{Acknowledgements}

The authors wish to thank the Department of Corn Diseases and Sugar Crops Research, Plant Pathology Research Institute, Agriculture Research Center, Giza, Egypt, for providing the field experiment.

\section{Authors' contributions}

Both authors read and approved the final manuscript.

\section{Ethics approval}

The authors declare that they have ethics approval and consent to participate.

\section{Competing interests}

The authors declare that they have no competing interests.

\section{Publisher's Note}

Springer Nature remains neutral with regard to jurisdictional claims in published maps and institutional affiliations.

\section{Author details}

${ }^{1}$ Plant Pathology Department, National Research Centre, Giza, Egypt. ${ }^{2}$ Plant Nutrition Department, National Research Centre, Giza, Egypt.

Received: 12 March 2018 Accepted: 16 May 2018

Published online: 29 May 2018

\section{References}

Abd El-Migeed A, El-Sayed AB, Hassan HS (2004) Growth enhancement of olive transplants by broken cells of fresh green algae as soil application. Minufia J Agric Res 29(3):723-737

Abd El-Motty EZ, Shahin MF, El-Shiekh MH, Abd-El-Migeed M (2010) Effect of algae extract and yeast application on growth, nutritional status, yield and fruit quality of Keitte mango trees. American-Eurasian J Agric Environ Sci 1(3):421-429

Ainsworth GC, James PW (1971) Ainsworth and Bisby's dictionary of fungi, 6th edn. Commonwealth Mycological Institute, Kew, Surrey, UK, p 612
Alhanshoul AM (2015) Studies on maize late wilt disease caused by Cephalosporium maydis. Ph.D. thesis. Fac. Agric., Cairo Univ., Egypt, p 166 Ali M (2000) Diversity in isolates of Cephalosporium maydis the causal of late wilt of maize in Egypt. M.Sc. Thesis. Fac. Agric., Cairo Univ., Egypt, p 120

Anonymous (2017) Bulletin of the agricultural statistics. Ministry of Agric. and Land Reclamation, Egypt, p 215

Ashour AM, Sabet KA, El-Shabrawy EM, Alhanshoul AM (2013) Control of maize late wilt and enhancing plant growth parameters using rhizobacteria and organic compounds. Egypt J Phytopath 41(2):187-207

Bell DK, Wells HD, Markham CR (1982) In vitro antagonism of Trichoderma species against six fungal plant pathogens. Phytopath 72:379-382

Benítez T, Rincón AM, Limón MC, Codón AC (2004) Biocontrol mechanisms of Trichoderma strains. Inter Microbiol 7:249-260

Cheng YU, Shen Zheng YI, Labavitch JM, VanderGheynst JS (2011) Impact of cell wall carbohydrate composition on the chitosan flocculation of Chlorella. Process Biochem 46:1927-1933

Degani O, Drori R, Goldblat Y (2015) Plant growth hormones suppress the development of Harpophora maydis, the cause of late wilt in maize. Physiol Molec Biol Plants 21(1):137-149

Dubois M, Gilles KA, Hamilton JK, Rebers PA, Smith F (1956) Colorimetric method for determination of sugars and related substances. Anal Chem 28:350-356

El-Shafey HA, Abd-el-Rahim MF, Abd-el-Azim OZ, Abd-el-Hamid MS (1976) Carryover of maize stalk-rot fungi in seed. Agric Res Rev 54:29-42

El-Mehalowy AA, Hassanein NM, Khater HM, Daram El-Din EA, Youssef YA (2004) Influence of maize root colonization by rhizosphere actinomycetes and yeast fungi on plant growth and on the biological control of late wilt disease. Inter J Agric Biol 6:599-605

El-Sayed AB, Abdalla FE, Abdel-Maguid AA (2001) Use of some commercial fertilizer compounds for Scenedesmus cultivation. Egyptian J of Phycology 2:9-16

El-Sayed AB, Battah MG, El-Sayed EW (2015) Utilization efficiency of artificial carbon dioxide and corn steam liquor by Chlorella vulgaris. Biolife 3(2):391-403

El-Shafey HA, Claflin LE (1999) Late wilt. In: White DG (ed) Compendium of corn diseases, $3^{\text {rd }}$ ed. The American Phytopathological Society, St. Paul, pp 43-44

El-Shafey HA, El-Shorbagy FA, Khalil I, El-Assiuty EM (1988) Additional sources of resistance to the late-wilt disease of maize caused by Cephalosporium maydis. Agric Res Rev 66:221-230

Elshahawy IE, Haggag K, Abd-El-Khair H (2016) Compatibility of Trichoderma spp. with seven chemical fungicides used in the control of soil borne plant pathogens. Res J Pharm Biol Chem Sci 7(1):1772-1785

Elshahawy IE, Saied N, Abd-El-Kareem F, Morsy A (2017b) Biocontrol of onion white rot by application of Trichoderma species formulated on wheat bran powder. Arch Phytopathol Plant Prot 50(3-4):150-166 
Elshahawy IE, Saied NM, Morsy AA (2017a) Fusarium proliferatum, the main cause of clove rot during storage, reduces clove germination and causes wilt of established garlic plants. J Plant Pathol 99(1):81-89

García-Carneros AB, Girón I, Molinero-Ruiz L (2012) Aggressiveness of Cephalosporium maydis causing late wilt of maize in Spain. Commun Agric Appl Biol Sci 77(3):173-179

Hassan SY, Mohamed ZM, El- Sayed AB (2015) Production and evaluation of pasta supplemented with Spirulina platensis biomass. Adv Food Sci 37(4):153-162

Johnson LF, Curi EA, Bond JH, Fribourg HA (1960) Methods for studying soil microflora-plant disease relationship, 2nd edn. Burgess Publishing Company, Minneapolis, p 119

Labib HA, Abdel-Rahim MF, Salem A, Abdel-Fattah A (1975) A new maize hybrid seed resistant to late wilt disease caused by Cephalosporium maydis. Agric Res Rev 53:1-4

Liu L, Pohnert G, Wei D (2016) Extracellular metabolites from industrial microalgae and their biotechnological potential. Review, Mar Drugs 14(191):1-19

Metcalf DA (1997) Biological control of onion white root rot (Sclerotium cepivorum) using Trichoderma koningii. Ph.D. thesis. University of Tasmania, Australia, p 118

Morsy A, Elshahawy IE (2016) Anthracnose of lucky bamboo Dracaena sanderiana caused by the fungus Colletotrichum dracaenophilum in Egypt. J Adv Res 7 : 327-335

Nelson DL, Cox MM (2008) Lehninger's principles of biochemistry. Freeman and Company, New York, p 115

Raposo MFDJ, Morais SCD (2011) Chlorella vulgaris as soil amendment: influence of encapsulation and enrichment with Rhizobacteria. Int J Agric Biol 13:719-724

Sabet KA, Samra AS, Mansour IM (1970) Saprophytic behavior of Cephalosporium maydis and C. acremonium. Ann Appl Biol 66:265-271

Safi C, Zebib B, Merah O, Pontalier P, Vaca-Garcia C (2014) Morphology, composition, production, processing and applications of Chlorella vulgaris: a review. Renew Sust Energ Rev 35:265-278

Saleh AA, Leslie JF (2004) Cephalosporium maydis is a distinct species in the Gaeumannomyces-Harpophora species complex. Mycologia 96(6):1294-1305

Samra AS, Sabet KA, Hingorani MK (1963) Late wilt disease of maize caused by Cephalosporium maydis. Phytopath 53:402-406

Shabaan MM (2010) Green microalgae water extracts as foliar feeding to wheat plants. Pak J Biol Sci 4:628-632

Singh S, Kate BN, Banerjee UC (2005) Bioactive compounds from cyanobacteria and microalgae: an overview. Critical Rev Biotech 25:73-95

Song T, Martensson L, Eriksson T, Zheng W, Rasmussen U (2005) Biodiversity and seasonal variation of the cyanobacterial assemblage in a rice paddy field in Fujian, China. The Federation of Europ Materials Societies Microbiol Ecol 54:131-140

Spinelli F, Giovanni F, Massimo N, Mattia S, Guglielmo C (2009) Perspectives on the use of a sea weed extract to moderate the negative effects of alternate bearing in apple trees. J Horti Sci Biotech 17(1):131-137

Stadnik MJ, Freitas MB (2014) Algal polysaccharides as source of plant resistance inducers. Tropical Plant Pathol 39(2):111-118

Stewart L, Schluter PJ, Shaw GR (2006) Cyanobacterial lipopolysccharides and human health. A review. Enviro Health 5:1-7

Taha TM, Youssef MA (2015) Improvement of growth parameters of Zea mays and properties of soil inoculated with two Chlorella species. Rep Opin 7(8): 22-27

Wake H, Akasaka A, Unetsu H, Ozeki Y, Shimomura K, Matsunaga T (1992) Enhanced germination of artificial seeds by marine cyanobacterial extract. Appl Environ Microbiol 36:684-688

Zayadan BK, Matorin DN, Baimakhanova GB, Bolathan K, Oraz GD, Sadanov AK (2014) Promising microbial consortia for producing biofertilizers for rice fields. Microbiol 83:391-397

Zeller KA, Ismael AS, El-Assiuty EM, Fahmy ZM, Bekheet FM, Leslie JF (2002) Relative competitiveness and virulence of four clonal lineages of Cephalosporium maydis from Egypt toward greenhouse-grown maize. Plant Dis $86: 373-378$

\section{Submit your manuscript to a SpringerOpen ${ }^{\circ}$ journal and benefit from:}

- Convenient online submission

- Rigorous peer review

- Open access: articles freely available online

- High visibility within the field

- Retaining the copyright to your article

Submit your next manuscript at $>$ springeropen.com 